Review

\title{
Susceptibility to Coronavirus (COVID-19) in Occupational Settings: The Complex Interplay between Individual and Workplace Factors
}

\author{
Veruscka Leso (D), Luca Fontana (D) and Ivo Iavicoli *(D)
}

Citation: Leso, V.; Fontana, L.; Iavicoli, I. Susceptibility to Coronavirus (COVID-19) in Occupational Settings: The Complex Interplay between Individual and Workplace Factors. Int. J. Environ. Res. Public Health 2021, 18, 1030

https://doi.org/10.3390/ijerph18031030
Department of Public Health, Section of Occupational Medicine, University of Naples Federico II, Via S. Pansini 5 , 80131 Naples, Italy; veruscka.leso@unina.it (V.L.); luca.fontana@unina.it (L.F.)

* Correspondence: ivo.iavicoli@unina.it; Tel.: +39-081-7462-430
Received: 29 December 2020

Accepted: 22 January 2021

Published: 25 January 2021

Publisher's Note: MDPI stays neutral with regard to jurisdictional claims in published maps and institutional affiliations.

Copyright: (c) 2021 by the authors. Licensee MDPI, Basel, Switzerland. This article is an open access article distributed under the terms and conditions of the Creative Commons Attribution (CC BY) license (https:/ / creativecommons.org/licenses/by/ $4.0 /)$.

\begin{abstract}
In the current coronavirus (COVID-19) pandemic, the definition of risk factors for susceptibility to adverse outcomes seems essential to support public and occupational health policies. Some specific issues need to be addressed to understand vulnerability in occupational settings. Among these, individual factors, e.g., age, sex, and preexisting comorbidities (hypertension, cardiovascular diseases, diabetes, obesity, cancer), that can predispose individuals to more severe outcomes and postCOVID-19 symptoms that may represent conditions of acquired susceptibility, possibly impacting the return to-and fitness for-work. Additionally, the risk of contracting COVID-19 through work should be addressed, considering the probability of being in contact with infected people, physical proximity to others, and social aggregation during work. Occupational health settings may represent appropriate scenarios for the early identification of vulnerable subjects, with the final aim to guide risk assessment and management procedures. These should include the systematic surveillance of work-related risk factors, collective preventive policies, stringent actions for specific groups of workers, decisions on occupational placement of employees, and health promotion activities. Concerted actions of general practitioners, hospital specialists, occupational physicians, and all the stakeholders involved in the occupational health and safety management should be focused on planning suitable preventive measures for susceptible subjects.
\end{abstract}

Keywords: SARS-CoV-2; vulnerability; frailty; risk factors; severe COVID-19; mortality; comorbidities; risk assessment; risk management; occupational health

\section{Introduction}

In the current coronavirus (COVID-19) pandemic, the definition of risk factors for susceptibility to adverse and mortality outcomes represents an essential tool to support disease management issues. This can be useful to better define the clinical and epidemiological characteristics of the disease and to facilitate decision-making regarding the appropriate care for patients. From a preventive perspective, considering that countries are adapting to the longer-term challenges of COVID-19, a deeper knowledge of suscetibility risk factors may provide guidance for the development of suitable policies to protect the public and occupational health [1].

To this aim, it is important to consider the huge toll paid by frail people in terms of severe clinical manifestations, access to intensive care units and mortality, in the early stage of the COVID-19 pandemic. Although frailty has its own clinical definition, as it is intended as "a medical syndrome with multiple causes and contributors, that is characterized by diminished strength, endurance and reduced physiologic function that increases an individual's vulnerability for developing increased dependency and/or death" [2,3], data extrapolated from the experience of frail patients may be useful to identify conditions of susceptibility requiring specific preventive actions to possibly avoid the infection and achieve better management of the disease. 
Since its first recognition in China in December 2019, the disease has spread around the globe at an unprecedented pace. At the time this review was written, more than 76 million confirmed cases of COVID-19, including more than 1,700,000 deaths, have been reported worldwide [4]. The US has experienced more deaths from COVID-19 than any other country and has one of the highest cumulative per capita death rates [5]. Italy has been one of the first and most severely affected countries [6], with 1,977,370 confirmed cases of COVID-19 and 69,842 deaths from 3 January to 23 December 2020 [7].

Additionally, worldwide reports have confirmed the high risk of severe illness from COVID-19, including the need for hospitalization, intensive care and death, in older adults, particularly in those with comorbidities (e.g., cardiovascular and respiratory diseases, morbid obesity, diabetes, chronic kidney disease, cancer, gastrointestinal, skin, muscleskeletal, and immune diseases) [8-13].

Acquiring this kind of information seems critically important for occupational physicians who are increasingly asked to advise on the fitness for work of patients who may be unusually vulnerable to the disease. It is essential to support employers in the adoption of suitable preventive and protective measures, including collective, individual, or organizational interventions, aimed to protect the health of workers, particularly for those at higher risk of unfavorable outcomes. In this scenario, additional efforts for occupational physicians are required to define the complex interplay between susceptibility conditions to COVID-19 with respect to specific occupational contexts and risk factors. Therefore, the aim of this narrative review is to provide an updated overview on possible individual risk factors predictive for unfavorable mortality and morbidity outcomes that may inform risk assessment and management in workplace scenarios, with the perspective to identify knowledge gaps and future research needs in this field.

\section{Literature Search}

Advanced searches on PubMed, Scopus, and ISI Web of Science databases were conducted to identify studies published until the 20 December 2020, evaluating possible physiological or pathological conditions of susceptibility to SARS-CoV-2 infection and adverse outcomes, as well as relevant issues to be considered for the consequent risk assessment and management processes in different occupational sectors, taking into particular account the protection of vulnerable workers.

We used two search lines that included the terms "COVID-19" or "SARS-CoV-2", combined with "frailty" or "susceptibility" or "vulnerability", which were further combined with additional individual terms referring to possible conditions influencing disease manifestation and course: "age", "gender", "cardiovascular disease*", "diabetes", "overweight and obesity", "cancer", "respiratory disease ${ }^{* ",}$, "autoimmune disease" of duplicates, the titles and abstracts of the articles retrieved through the computerized search were independently examined by two of the authors. All types of human peerreviewed research articles (i.e., descriptive epidemiological surveys, cross-sectional, cohort, case-control studies, case series), as well as review papers, were included. Only studies published in languages other than English and publications not specifically focusing on the topics of the review were excluded. For the section on occupational risk factors for susceptibility to COVID-19, the first two search lines were combined with the terms "occupational risk assessment" and "occupational risk management". Furthermore, some additional documents belonging to the gray literature from national and international governmental and research institutes involved in occupational health and safety management were considered for inclusion.

As the review process was not intended to be systematic, and the idea of the authors was to provide inputs on relevant topics in the occupational health practice, articles considered better representative of relevant issues in the respective fields were discussed among the authors and finally included in such a critical revision. The following paragraphs will attempt to summarize important aspects regarding individual and occupational risk factors for COVID-19 that should be carefully considered for adequate protection of the health of 
workers, particularly for those with conditions of greater susceptibility to acquire and have a more severe course of the disease.

\section{Individual Risk Factors for SARS-CoV-2 Susceptibility}

\subsection{Age}

A great series of epidemiological and observational studies demonstrated an increased number of cases and a greater risk of severe and fatal disease with increasing age [14-19]. Older peoples' immune-senescence may be characterized by the disruption in both innate and adaptive arms of the immune system, which is not efficient enough to limit infection, as demonstrated by the higher peak viral load in the nasopharynx determined in older adults $[20,21]$. This results in an increased vulnerability and poor resolution of homeostasis following stress, which may lead to low resilience and frailty. In addition, it seems that very high pro-inflammatory cytokine release, which is described as a cytokine storm, is a pivotal pathophysiological mechanism in elderly COVID-19 patients [22]. Although the exact underlying mechanism of cytokine storm in elderly adults with severe COVID-19 infection is far from clear, it is likely that such dysregulation of the cytokine homeostasis may play a critical role in the development of the acute respiratory distress syndrome (ARDS) in some elderly patients. Many age-related pathophysiologic processes have been suggested as potentially related to such "inflame-aging phenomenon", among those, the alteration of the expression of the angiotensin-converting enzyme 2 (ACE2) receptor [23], the excessive reactive oxygen species production [24], the autophagy alterations [25], the inflammatory phenotype of senescent cell activity, particularly adipose tissue [26], and immune-senescence [27], as well as lack of vitamin D content [28]. Additionally, agingrelated worst outcomes may be dependent on the intrinsic pathophysiological changes that characterize the respiratory system, as well as by the increasing presence of chronic comorbidities with increasing age [29]. However, attention should be paid to consider chronological age per se without considering that individuals do not age the same and that the underlying mechanisms of aging may be different between subjects.

\subsection{Gender}

First reports from China have pointed out a sex imbalance with regard to detected cases and case fatality rate of COVID-19 [30-33]. The largest body of publicly available sex-disaggregated data demonstrated no gender-related differences in the number of confirmed cases, with $45.7 \%$ female vs. 54.3\% male cases in September 2020 [34,35], in line with previously published data $[36,37]$. However, the overall case-fatality ratio was approximately 2.4 times higher among men than among women [38,39]. Clinical and epidemiological evidence from China [37], the US [40], the UK [41] and European countries (Italy, Spain, France, Germany and Switzerland) [36] demonstrated a 60\% to 80\% increase in the risk of death for males compared to females. The diverse regulation of the immune system determined both by sex chromosome genes, and sex hormones can be responsible for gender-related differences in COVID-19 mortality [38,42,43]. Moreover, the higher tissue expression of the ACE2 receptors for SARS-CoV-2 in men can cause a greater susceptibility to the infection $[44,45]$. Psychosocial and behavioral factors can also play a role [46-48]. In fact, due to a different belief of the pandemic severity, men tend to engage in more high-risk behaviors, have lower rates of social distancing, wearing masks, and seeking medical help compared to women, thus enhancing the possibility for SARS-CoV-2 infection [49-51]. Smoking and drinking rates are higher among men than women, and such behaviors may be associated with the risk of developing comorbidities [36]. Possible differences in occupational risks between men and women may account for diverse COVID19 outcomes. In the US, women are primarily employed in social and healthcare activities, while men are mainly involved in low-skilled or low-paid essential occupations, e.g., food processing, transportation, delivery, warehousing, construction, manufacturing, where men may experience a greater risk of mortality [52]. 


\subsection{Cardiovascular Risk Factors}

Hypertension has been reported as the most common comorbidity among patients infected with SARS-CoV-2, with a prevalence ranging from 10-15\% to more than 50\% [53-58]. Hypertension has been proven to be associated with an increased risk of pneumonia, as well as acute respiratory disease and chronic low respiratory disorders independent of age, sex, smoking status and BMI $[59,60]$. The prevalence of hypertension was higher in patients with severe COVID-19 [61-64] and with lethal outcomes [65-68] with respect to non-severe cases. However, to achieve a correct interpretation of these data, it should be noted that hypertension is commonly diagnosed in aged populations, and it is accompanied by many comorbidities, i.e., obesity, diabetes, and cardiovascular diseases (CVDs), that may function as major determinants for COVID-19 severity. Concerning age, hypertension was reported in percentages ranging from $44.7 \%$ of the 55-64 years old Chinese population [69], in the $45.2 \%$ of the Italian population aged $60-69$ years [70], up to the $63-77 \%$ of the US 55-64 years general population [71]. Overall, this underlines the relevance to further understand whether hypertension was a predictor of mortality independently of other concomitant risk factors [63].

Additionally, also CVDs, i.e., heart failure and arrhythmia, appear as risk factors for severe complications of COVID-19 [53]. Patients with a previous history of CVDs were up to 4 and 6 times more likely to develop the severe and lethal disease, respectively [72]. In line with these findings, data from the Chinese Center for Disease Control and Prevention pointed to a $10.5 \%$ mortality rate in COVID-19 patients with CVD compared to a lower $2.3 \%$ rate in the overall infected population [73]. Moula et al. [74], in a meta-analysis, assessed the predictive role of different CVDs and coronary artery disease (CAD) separately with respect to COVID-19 mortality. The presence of other CVDs is a strong predictor of death. In fact, a 1.96- and 1.90-fold higher mortality risk was reported in patients with overall CVD and $\mathrm{CAD}$ alone, respectively, while these 2 conditions combined were found to increase the risk up to 2.03-fold. Cerebrovascular disease is a strong predictor of death as patients with the preexisting cerebrovascular disease tend to die 2-fold more than patients without cerebrovascular disease $[74,75]$. In addition to a history of CVD, being an aggravating factor in COVID-19 development, cardiovascular complications can also be the result of the infection, both through a direct SARS-CoV-2 induced myocardial injury as well as by an indirect action exerted by the acute respiratory distress syndrome and systemic illness [76-78].

\subsection{Diabetes}

Most of the available information refers to patients with type 2 diabetes. This disease per se does not seem to increase the risk of contracting COVID-19 [79]. The prevalence of type 2 diabetes in patients with COVID-19 has been reported to be around 9-12\% [80-82], raising up to $16-35 \%$ in hospitalized patients, including those who required intensive care for the severe disease [83-85]. Type 2 diabetes, in fact, has been reported to be more often associated with severe or critical disease, including ARDS, multiorgan failure and death, varying from 14 to $32 \%$ in different studies [59,86-88]. Additionally, in a summary report of 44,672 confirmed COVID-19 cases, the Chinese Center for Disease Control and Prevention reported an increased case fatality rate in diabetes $(2.3 \%$ overall and $7.3 \%$ in diabetic patients) [89].

As regards different types of diabetes, a UK survey found that among 23,804 COVID19 patients died in hospital, $32 \%$ had type 2 diabetes, and $1.5 \%$ had type 1 diabetes, with 2.03 and 3.5 times the odds of dying compared with patients without diabetes, respectively. A multicenter observational French study, that was performed on 1317 diabetic patients hospitalized for COVID-19, showed that $3 \%$ had type 1 diabetes, while $88.5 \%$ were affected by type 2 disease [90].

Concerning the impact of glycemic control on COVID-19 mortality, patients with an $\mathrm{HbA} 1 \mathrm{c}$ of $86 \mathrm{mmol} / \mathrm{mol}(10.0 \%)$ or higher had increased COVID-19-related mortality compared to people with an $\mathrm{HbA} 1 \mathrm{c}$ of $48-53 \mathrm{mmol} / \mathrm{mol}(6.5-7.0 \%)$, with a hazard ratio 
of 2.23 and 1.61 in type 1 and type 2 diabetes, respectively. In addition, in people with type 2 diabetes, those with an $\mathrm{HbA1c}$ of $59-74 \mathrm{mmol} / \mathrm{mol}(7.6-8.9 \%)$ and $75-85 \mathrm{mmol} / \mathrm{mol}$ (9.0-9.9\%) showed a significantly higher COVID-19 mortality compared with those with an $\mathrm{HbA} 1 \mathrm{c}$ of $48-53 \mathrm{mmol} / \mathrm{mol}$, with an HR of 1.22 and 1.36, respectively [91].

In summary, a worse prognosis is expected in patients with diabetes affected by COVID-19, most probably because of the concurring effect of multiple factors, i.e., age, comorbidities (hypertension, CVDs and obesity), and glycemic control before-, at the time of- and during hospital admission [79]. Many uncertainties still remain regarding the mechanisms linking diabetes with a more severe course of the disease. The high expression of ACE2 receptors used by SARS-CoV-2 to enter human cells, poor glucose control and high glycemic variability, preexisting diabetes-induced target organ damage, increased inflammatory factors, and hyper-coagulability can be responsible for higher susceptibility of diabetic patients to the adverse outcomes of the infection [82,92].

\subsection{Overweight and Obesity}

Emerging evidence supports excessive body weight and obesity as risk factors for more serious COVID-19 disease and fatal outcomes [93-96]. A retrospective analysis of the body mass index (BMI) in USA SARS-CoV-2 infected patients demonstrated that subjects aged $<60$ years with a BMI between 30 and 34 and $>35$ were about two and four times more likely to be admitted to acute and critical care compared to individuals with a BMI < 30 [97], respectively. Other case studies confirmed obesity as a major risk factor for disease severity and intensive care unit requirements both in the US [53,83], China [98], the UK [99], France [100,101], Germany [102], and Italy [103,104]. COVID-19 deaths were also more frequently associated with obesity in several countries [105-107]. In line with these results, a recent meta-analysis including 30 studies for a total of 45,650 participants demonstrated that BMI defined obesity was significantly associated with a higher risk for severe COVID-19 including, hospitalization (OR 2.36), intensive care unit (ICU) admission (OR 2.32) and invasive mechanical ventilation (OR 2.63), as well as for mortality (OR 1.49) [108]. Further, excessive visceral adiposity appeared to be significantly associated with severe COVID-19 outcomes [108,109].

The contribution of overweight/obesity to a more severe disease has biological and physiological plausibility. Obesity is characterized by abnormal secretion of several proinflammatory adipokines and cytokines from the adipose tissue, i.e., tumor necrosis factoralfa, interleukin (IL)-1, IL-6, and monocyte chemoattractant protein, which are responsible for a low-grade, chronic pro-inflammatory state that may predispose to a greater COVID-19 severity $[100,110,111]$. Obesity may indirectly impact COVID-19 outcomes impairing lung function and respiratory system compliance to mechanical ventilation, thus placing these patients at high risk of severe illness and mortality [112]. In addition to the detrimental effects on lung function, obesity is a well-known risk factor for diabetes, hypertension and CVDs, all predictors of poor outcomes [93].

\subsection{Cancer}

Cancer patients are regarded as a highly vulnerable group due to weakened immune systems caused by both tumor growth and anticancer treatment $[59,113,114]$. In a nationwide cohort study on 2007 Chinese patients, Liang et al. [115] demonstrated that cancer patients had poorer outcomes from COVID-19. In fact, 39\% of cancer patients experienced severe events, including ICU admission, need for invasive ventilation, or death, compared with only $8 \%$ of noncancer COVID-19 patients. Comparably, the analysis of data from the COVID-19 and Cancer Consortium (CCC19) cohort study on 928 cases also reported that 30 day-mortality and severe illness in COVID-19 cancer patients were significantly higher than the general population [116]. The most common malignancies in Kuderer et al. [116] were breast (21\%) and prostate (16\%) cancer; $43 \%$ had measurable cancer while $39 \%$ were on active cancer treatment. 
Among 3000 early COVID-19 cases from Italy, a previous (5 years) history of cancer was reported by $20 \%$ of non-survivor patients [9]. Higher rates of death, ICU admission, need for invasive mechanical ventilation, the manifestation of at least one severe or critical symptom was reported by Dai et al. [117] on 105 cancer patients. In this population, the most frequent cancer type was lung cancer $(20.95 \%)$, followed by gastrointestinal $(12.38 \%)$, breast $(10.48 \%)$, thyroid $(10.48 \%)$ and hematological cancers $(8.57 \%)$. Moreover, the highest frequency of severe complications was reported in patients with hematological, lung, or metastatic cancer (stage IV). Concerning the role of treatment, patients who received surgery or an anticancer treatment within 14 days before COVID-19 diagnosis had higher risks of having severe events compared to patients without cancer, while such increase was not evident in those receiving only radiotherapy $[118,119]$. Patients who underwent chemotherapy or surgery in the prior month had a significantly higher risk $(75 \%)$ of clinically severe events than those who did not receive chemotherapy or surgery (43\%) [115]. Similarly, another study of 205 COVID-19 cancer patients showed that receiving chemotherapy within four weeks before symptoms onset and male sex were risk factors for death [120].

\subsection{Respiratory Diseases}

The association between respiratory diseases and severe COVID-19 outcomes has not been definitively clarified. Concerning the prevalence of respiratory diseases among 13,184 patients with COVID-19, a recent metanalysis demonstrated that the chronic obstructive pulmonary disease (COPD) was the main respiratory disease documented [121], and only one study also reported pulmonary tuberculosis and asthma [122]. A significantly 4-fold higher odds of severe COVID-19 outcomes were determined in patients with underlying respiratory diseases, a result in line with those previously obtained by Yang et al. [123] in a smaller meta-analysis. A nearly four-to six-fold higher risk of developing severe COVID-19 was associated with the presence of COPD [121,124], although no significant association could be extrapolated for mortality association [124]. Few available studies have reported a high prevalence of asthma among COVID-19 patients, preventing definite conclusions $[125,126]$.

\subsection{Autoimmune Diseases}

No definite conclusions can be extrapolated concerning the risk for COVID-19 infection and for more severe manifestations in patients with systemic autoimmune diseases in comparison with the general population with similar comorbidities [127-131]. A metaanalysis performed on 62 observational studies on autoimmune diseases that affected patients demonstrated that the prevalence of COVID-19 was 0.011 [128]. Among the seven case-controlled studies available, including psoriasis and rheumatic patients, the risk for COVID-19 was significantly higher than in controls (OR 2.19). This finding was also confirmed in an Italian series of systemic autoimmune diseases [129]. However, this was primarily attributed to the glucocorticoid use, while other therapies, including conventional (i.e., methotrexate, hydroxychloroquine, and sulfasalazine) or biological or target synthetic (i.e., infliximab, adalimumab, etanercept, tofacitinib) disease-modifying antirheumatic drugs (DMARDs) did not contribute to the risk [128]. No evidence for differences in hospitalization, ICU admission, mechanical/non-invasive ventilation, and death emerged from several investigations in comparison to the general population [128,132,133]. Only therapies with glucocorticoids, conventional DMARDs, combined conventional syntheticbiological/target synthetic DMARDs had a 2-3 times higher event rate of each clinical outcome when compared with biological-target synthetic DMARDs alone [128].

\section{Occupational Risk Factors for SARS-CoV-2 Susceptibility}

In workplace settings, the story is not simply one of understanding and grading individual risk factors, but also to put individual conditions in relation to the risk of contracting COVID-19 through work. In fact, in a complementary manner, occupational 
analysis can address workplace environmental risk of exposure to and acquisition of infection, while personal features can determine the impact of infection once acquired [134]. From an occupational health perspective, it is clear that susceptibility should be considered as the result of the complex interplay between individual and the job or task features. This regards several types of working conditions, like healthcare and social works, where biological risks are intrinsically related to the job activities, but also other occupational sectors for which the risk of infection is comparable to that of the general population.

Therefore, work has been recognized as a key determinant in the risk of infection [135]. Multiple outbreaks of COVID-19, in fact, have been reported in a variety of occupational fields, including food packaging and processing sectors, factories and manufacturing departments, and office settings [136]. As an ulterior confirmation, the analysis of the Italian compensation claims pointed out that the SARS-CoV-2 infection has been acquired at the workplace in a substantial number of cases (19.4\% of the total amount) [137]. The probability of being in contact with infected people, the physical proximity to others during work activities, and the social aggregation connected to the job may function as key determinants in workplace SARS-CoV-2 transmission $[135,138]$. In the absence of control measures, a higher risk of infection may be experienced by workers involved in occupations in which it is difficult to maintain physical distancing from coworkers, customers, patients, as well as by employees performing work activities in indoor settings or with shared transport or accommodation [136].

In this scenario, methodological approaches have been developed to estimate the levels of the risk of infection associated with various worksites. These first explore the exposure probability due to specific work tasks, including where, how, and to what sources workers may be exposed to SARS-CoV-2. Such sources may be represented by the general public, customers, and coworkers; sick individuals, like in the case of healthcare workers, or those at particularly high risk of infection, but also non-occupational risk factors at home and in community settings depending on the local infection prevalence [139]. Additionally, the extent to which the job entails either close proximity to people who may carry the infection or contact with materials that may be contaminated by the virus, aggregation factors as well as the effectiveness of any measure to reduce transmission, i.e., barriers or personal protective equipment, as well as how the individual commutes to work should be deeply assessed [138].

According to all these aspects, job tasks may be categorized into different levels of exposure risk. From very high exposure risk jobs, like those in which healthcare or laboratory workers are exposed to aerosol-generating medical maneuvers or lab procedures requiring collecting or handling specimens from known or suspected COVID-19 patients, respectively, to high, medium and lower exposure risk jobs. This latter group includes jobs not requiring contact with people known or suspected to be infected with SARS-CoV-2 nor frequent close contact with the general public [139]. The importance of such classification relies on the corresponding preventive and protective protocols to be adopted to mitigate workplace transmission and the prompt identification and isolation of potentially infectious individuals within the company. According to the "hierarchy of controls", such strategies may include (i) to remove or reduce the exposure at the source, e.g., through flexible work solutions, where possible, screening, testing, case investigating and contact tracing; (ii) to redesign the work environments with the adoption of barriers and protection elements to facilitate social distancing, and the implementation of areas for frequent hand washing and sanitizations; (iii) to support the adoption of organizational preventive measures in the workplace; (iv) to promote health and safety education of individual workers and the employment of personal protective equipment in order to minimize the exposure of receptors [140].

However, suitable risk assessment and management strategies in the workplace should also integrate susceptibility evaluation and careful considerations of specific conditions of the individuals, e.g., older age, presence of chronic medical conditions, including immunocompromising ones. These issues appear extremely important considering the 
global aging of the workforce $[141,142]$ and the growing population of immunosuppressed people who enter or reenter the workforce [143]. Overall, this perspective allows moving of the risk assessment from a population-based to an individually personalized approach. Moreover, it, inevitably, underlines the central role of occupational physicians in integrating personal information with job or task features as a unique opportunity to achieve suitable management of susceptible individuals at work.

Risk assessment models should offer the possibility to quantify the vulnerabilities associated with demographic variables and comorbidities and their possible combined impact with occupational features in order to measure the equivalent increase in risk that may predict severe courses and case-fatality rate $[1,144,145]$. Age, gender, ethnicity and comorbidities are commonly included in occupational risk assessment tools, while measures of social circumstances are less frequently assessed [134]. This risk categorization should support individually tailored preventive and protective measures regarding workplace adaptations (e.g., unrestricted work or work-restricted to certain patient groups) or actions (e.g., staff redeployment or home working). However, caution should be paid in the application of such tools for workplace policymaking. Some limitations should be carefully considered, including the focus on the relative risk that is not able to assess whether the absolute risk is actually low, intermediate or high, and the possible lack of accuracy of such points score instruments where multiple risk factors co-exist that may provide an artificial classification of the risk. Finally, by addressing only "individual factors," the scores do not include the interaction between these and the working environment or job task features. This points out the relevance of developing advanced models able to integrate all these aspects in order to have better representative risk assessment measures. Overall, clinical judgments, technical considerations, and prevailing advice from the government need to be carefully considered in managing occupational risks from COVID-19.

\section{Discussion}

The ongoing COVID-19 pandemic still requires a deeper understanding of the nature of the disease and its suitable treatment or preventive measures, as well as how to best safeguard public health in order to avoid the overwhelming of the health care system [146]. In this scenario, it also seems necessary to define appropriate strategies to identify and manage susceptible individuals with a higher risk of acquiring the disease and developing adverse outcomes. This means to translate data acquired on frail patients from clinical settings into a preventive perspective aimed to point out possible conditions of vulnerability that need specific attention and interventions in both public and occupational health contexts.

Concerning possible conditions of susceptibility to COVID-19, literature evidence reported age and sex as relevant demographic risk factors for more severe outcomes. Additionally, a list of underlying health conditions, particularly preexisting CVDs, diabetes mellitus, obesity and cancer were estimated to increase the risk for severe COVID-19. However, additional investigations are warranted to acquire a deeper knowledge with respect to the role of individual conditions or the association of personal and/or medical illnesses with respect to both the risk of acquiring COVID-19 and developing severe manifestations. In this regard, better-designed studies should be aimed to overcome possible limitations related to the self-reporting of comorbidities but also to the possible under-reporting of diseases due to the lack of awareness and/or diagnostic testing. A suitable duration of follow-up should also support the extrapolation of unbiased associations between comorbidities and clinical outcomes. Additionally, the limitations due to the heterogeneity of some categories of comorbidity should be overcome, i.e., chronic pulmonary disease aggregates various disorders that are characterized by a wide range of severity. Future investigations should allow evidence-based risk assessments for more specific subcategories of diseases or rarer comorbidities, also considering the detailed history of each condition and specific pathological characteristics. This may include disease onset and course, current 
or recent activity / flare-ups, past histories of hospital admissions, and medications (past, current or recent) used.

In the perspective of defining susceptibility conditions, a deep evaluation of possible consequences of SARS-CoV-2 infection should be included. In this view, the post-COVID19 syndrome has been defined "as signs and symptoms that develop during or following an infection consistent with COVID-19, which continue for more than 12 weeks and are not explained by an alternative diagnosis. The condition usually presents as clusters of symptoms, often overlapping, which may change over time and can affect any system within the body" [147]. Notably, post-COVID-19 patients may exhibit extra-pulmonary manifestations, including fatigue, generalized pain, persisting high-temperature and psychiatric problems, neurological, cardiovascular, and musculoskeletal disorders, burdening their functional status $[148,149]$. Indeed, also physical, sensorial, cognitive, and emotional consequences in COVID-19 survivors should also deserve further investigation in order to better define their link with the previous COVID-19, considering the nonspecificity of most of these symptoms. Moreover, also their possible function as conditions of acquired vulnerability that may have implications for fitness for work also in the view of broader management of return to work in the face of COVID-19 health risks should be deeply addressed [150]. In this context, efforts for risk profiling based on a comprehensive assessment and testing markers of susceptibility in relation to outcomes, detection of early warning symptoms and atypical presentations among patients with multimorbidity should be strongly pursued. This may regard to define, i.e., biomarkers and immune function indicators able to predict how older adults' immune responses help (or hinder) in fighting off the illness [151]. Finding possible biomarkers could be useful in identifying individuals at the highest risk for severe COVID-19 infection. Biomarkers may identify different risk management groups and yield important information on the mechanisms of severe disease. These may be associated with inflammation, endothelial function, mitochondria and apoptotic function, calcium homeostasis, fibrosis, neuromuscular function, sarcopenia, and bone/hormone metabolism and nutritional status [152,153].

As pointed out in previous paragraphs, on one hand, the work can impact a person's risk to contract the infection; on the other hand, demographic and pathological factors can influence COVID-19 severity. Both aspects are critical in determining the risk of a poor outcome and need to be carefully addressed. Therefore, an occupational risk assessment should include the evaluation of the level of work-based risk to become infected and its mitigation, and personal characteristics that may determine the different impact of the infection. In this perspective, the valuable participation of occupational physicians in risk assessment and management processes appears essential to define plans to protect vulnerable workers, to advise on the fitness for work and to develop a suitable epidemiological surveillance system, all priority measures in effective anti-COVID-19 workplace strategies $[1,135]$.

Additionally, it should be noted that the environmental and occupational risk, e.g., the prevalence of the disease at the community and hospital level, and the control strategies, e.g., measures to isolate infected patients, availability of personal protective equipment and vaccines, inevitably vary during the phases of the pandemic. This means that the risk assessment should not be viewed as a "one-off" process but as an iterative procedure to be updated when circumstances, whether environmental, occupational or individual, change. Overall, in actual conditions in which some uncertainties remain on several aspects, any risk assessment may be useful as a starting point for a discussion and the adoption of personalized preventive and protective plans [134]. To this aim, it seems important to underline that the complex interplay between the great variety of individual, physiological and pathological conditions and the huge spectrum of occupational realities requires a "case-by-case" approach to guide risk assessment and management measures. Any attempt to categorize personal or workplace features, in fact, can result in the failure of individually tailored preventive approaches that may result in an ineffective protection of susceptible workers. 
Occupational health settings may represent appropriate scenarios for the early identification of vulnerable subjects. However, this mission finds its strategic importance once it is able to guide risk assessment and management procedures. This latter may include the systematic surveillance of work-related risk factors, collective preventive policies, the adoption of more stringent actions specifically focused on particular groups of the population (e.g., stricter measures of personal hygiene; implemented personal protective equipment; prioritized access to the ongoing vaccine campaign), and decisions on occupational placement of workers (e.g., remote working; changes in job tasks) [151]. Suitable management strategies can also regard the need to implement the general preventive measures characterized by worker/patient information on occupational risk mitigations and education to recognize signs and symptoms of COVID-19, as well as to follow strict respiratory and hand hygiene. Health promotion activities tailored to support healthy behaviors, lifestyle, emotional health and wellbeing in vulnerable workers should be developed. Regular physical exercise and the use of functional food, smoking cessation programming and the importance of appropriate management of chronic conditions should be stressed in specifically focused populations [154-156]. The use of remote monitoring, teleconsultation, telemedicine and online apps and resources may be innovative means to achieve suitable risk communication, maintaining strong messaging to promote compliance with key protective behaviors. These tools can also assure vulnerable subjects regular follow-up, and constant provision of health, behavioral and psychological support, which may help in applying specific recommendations for facing COVID-19 related risks in the workplace.

\section{Conclusions}

A suitable assessment of susceptibility conditions will provide guidance to develop effective surveillance regimens both through strict testing plans intended to reduce the asymptomatic spread and the rapid activation of contact tracing to reduce transmission and overall mitigate the impact on vulnerable individuals [157]. Additionally, a deeper knowledge of vulnerability may be useful to establish priorities in vaccination strategies [158] and to define policies for the correct use of public resources of insurance systems [138]. Overall, additional studies should be aimed to verify the impact that policy measures adopted to face the pandemic may have on vulnerable groups. Certainly, as the knowledge about COVID-19 risks further develops, risk assessments and management for workplace risk factors and individuals, particularly vulnerable subjects, will need to be reviewed. Concerted actions of general practitioners, hospital specialists, occupational physicians and all figures involved in the health and safety management in the workplace should be strongly encouraged to plan suitable preventive measures for vulnerable subjects [159].

Author Contributions: Conceptualization, I.I.; literature revision, V.L.; writing-original draft preparation, I.I., V.L., L.F.; writing-review and editing, I.I., V.L.; supervision, I.I. All authors have read and agreed to the published version of the manuscript.

Funding: The research received no external funding.

Acknowledgments: The authors thank Pietro Apostoli for providing input and comments on earlier versions of the manuscript.

Conflicts of Interest: The authors declare no conflict of interest.

\section{References}

1. Coggon, D.; Croft, P.; Cullinan, P.; Williams, A. Assessment of workers' personal vulnerability to covid-19 using 'covid-age'. Occup. Med. 2020, 70, 461-464. [CrossRef] [PubMed]

2. Morley, J.E.; Vellas, B.; van Kan, G.A.; Anker, S.D.; Bauer, J.M.; Bernabei, R.; Cesari, M.; Chumlea, W.C.; Doehner, W.; Evans, J.; et al. Frailty consensus: A call to action. J. Am. Med. Dir. Assoc. 2013, 14, 392-397. [CrossRef] [PubMed]

3. Hewitt, J.; Carter, B.; Vilches-Moraga, A.; Quinn, T.J.; Braude, P.; Verduri, A.; Pearce, L.; Stechman, M.; Short, R.; Price, A.; et al. The effect of frailty on survival in patients with COVID-19 (COPE): A multicentre, European, observational cohort study. Lancet Public Health 2020, 5, e444-e451. [CrossRef] 
4. WHO, World Health Organization. WHO Coronavirus Disease (COVID-19) Dashboard. 2020. Available online: https://covid19. who.int/ (accessed on 24 December 2020).

5. Bilinski, A.; Emanuel, E.J. COVID-19 and Excess All-Cause Mortality in the US and 18 Comparison Countries. JAMA 2020, 324, 2100-2102. [CrossRef] [PubMed]

6. Remuzzi, A.; Remuzzi, G. COVID-19 and Italy: What next? Lancet Health Policy 2020, 395, 1225-1228. [CrossRef]

7. WHO, World Health Organization. WHO Coronavirus Disease (COVID-19). Global-Italy. 2020. Available online: https: / / covid19.who.int/region/euro/country/it (accessed on 24 December 2020).

8. Onder, G.; Rezza, G.; Brusaferro, S. Case-Fatality Rate and Characteristics of Patients Dying in Relation to COVID-19 in Italy. JAMA 2020, 323, 1775-1776. [CrossRef]

9. Docherty, A.B.; Harrison, E.M.; Green, C.A.; Hardwick, H.E.; Pius, R.; Norman, L.; Holden, K.A.; Read, J.M.; Dondelinger, F.; Carson, G.; et al. Features of 20133 UK patients in hospital with covid-19 using the ISARIC WHO Clinical Characterisation Protocol: Prospective observational cohort study. BMJ 2020, 369, m1985. [CrossRef]

10. Chakrabarty, B.; Das, D.; Bulusu, G.; Roy, A. Network-Based Analysis of Fatal Comorbidities of COVID-19 and Potential Therapeutics. Available online: https://chemrxiv.org/articles/preprint/Network-Based_Analysis_of_Fatal_Comorbidities_ of_COVID-19_and_Potential_Therapeutics/12136470/1 (accessed on 28 December 2020).

11. Andrew, M.; Searle, S.D.; McElhaney, J.E.; McNeil, S.A.; Clarke, B.; Rockwood, K.; Kelvin, D.J. COVID-19, frailty and long-term care: Implications for policy and practice. J. Infect Dev. Ctries 2020, 14, 428-432. [CrossRef]

12. Colaneri, M.; Sacchi, P.; Zuccaro, V.; Biscarini, S.; Sachs, M.; Roda, S.; Pieri, T.C.; Valsecchi, P.; Piralla, A.; Seminari, E.; et al. Clinical characteristics of coronavirus disease (COVID-19) early findings from a teaching hospital in Pavia, North Italy, 21 to 28 February 2020. Euro Surveill 2020, 25, 2000460. [CrossRef]

13. CDC-Centers for Disease Control-COVID-19 Response Team. Severe outcomes among patients with coronavirus disease 2019 (COVID-19): United States, February 12-March 16, 2020. MMWR Morb. Mortal. Wkly. Rep. 2020, 69, 343-346. [CrossRef]

14. Pence, B.D. Severe COVID-19 and aging: Are monocytes the key? Geroscience 2020, 42, 1051-1061. [CrossRef] [PubMed]

15. Wang, D.; Hu, B.; Hu, C.; Zhu, F.; Liu, X.; Zhang, J.; Wang, B.; Xiang, H.; Cheng, Z.; Xiong, Y.; et al. Clinical Characteristics of 138 Hospitalized Patients With 2019 Novel Coronavirus-Infected Pneumonia in Wuhan, China. JAMA 2020, 323, 1061-1069. [CrossRef] [PubMed]

16. Nikolich-Zugich, J.; Knox, K.S.; Rios, C.T.; Natt, B.; Bhattacharya, D.; Fain, M.J. SARS-CoV-2 and COVID-19 in older adults: What we may expect regarding pathogenesis, immune responses, and outcomes. Geroscience 2020, 42, 505-514. [CrossRef]

17. Ruan, Q.; Yang, K.; Wang, W.; Jiang, L.; Song, J. Clinical predictors of mortality due to COVID-19 based on an analysis of data of 150 patients from Wuhan, China. Intensive Care Med. 2020, 46, 846-848. [CrossRef] [PubMed]

18. Shahid, Z.; Kalayanamitra, R.; McClafferty, B.; Kepko, D.; Ramgobin, D.; Patel, R.; Aggarwal, C.S.; Vunnam, R.; Sahu, N.; Bhatt, D.; et al. COVID-19 and Older Adults: What We Know. J. Am. Geriatr. Soc. 2020, 68, 926-929. [CrossRef] [PubMed]

19. Liu, Y.; Mao, B.; Liang, S.; Yang, J.W.; Lu, H.W.; Chai, Y.H.; Wang, L.; Zhang, L.; Li, Q.H.; Zhao, L.; et al. Shanghai Clinical Treatment Experts Group for COVID-19. Association between age and clinical characteristics and outcomes of COVID-19. Eur. Respir. J. 2020, 55, 2001112.

20. Morley, J.E.; Vellas, B. Editorial: COVID-19 and Older Adults. J. Nutr. Health Aging 2020, 24, 364-365. [CrossRef]

21. Perrotta, F.; Corbi, G.; Mazzeo, G.; Boccia, M.; Aronne, L.; D’Agnano, V.; Komici, K.; Mazzarella, G.; Parrella, R.; Bianco, A. COVID-19 and the elderly: Insights into pathogenesis and clinical decision-making. Aging Clin. Exp. Res. 2020, 32, 1599-1608. [CrossRef]

22. Zhao, M. Cytokine storm and immunomodulatory therapy in COVID-19: Role of chloroquine and anti-IL-6 monoclonal antibodies. Int. J. Antimicrob. Agents 2020, 55, 105982. [CrossRef]

23. Yoon, H.E.; Kim, E.N.; Kim, M.Y.; Lim, J.H.; Jang, I.A.; Ban, T.H.; Shin, S.J.; Park, C.W.; Chang, Y.S.; Choi, B.S. Age-Associated Changes in the Vascular Renin-Angiotensin System in Mice. Oxid. Med. Cell Longev. 2016, 2016, 6731093. [CrossRef]

24. Garrido, A.; Cruces, J.; Ceprián, N.; Vara, E.; de la Fuente, M. Oxidative-Inflammatory Stress in Immune Cells from Adult Mice with Premature Aging. Int. J. Mol. Sci. 2019, 20, 769. [CrossRef] [PubMed]

25. Barbosa, M.C.; Grosso, R.A.; Fader, C.M. Hallmarks of Aging: An Autophagic Perspective. Front. Endocrinol. 2019, 9, 790. [CrossRef] [PubMed]

26. Stout, M.B.; Justice, J.N.; Nicklas, B.J.; Kirkland, J.L. Physiological Aging: Links among Adipose Tissue Dysfunction, Diabetes, and Frailty. Physiology 2017, 32, 9-19. [CrossRef] [PubMed]

27. Fuentes, E.; Fuentes, M.; Alarcón, M.; Palomo, I. Immune System Dysfunction in the Elderly. Anais da Academia Brasileira de Ciências 2017, 89, 285-299. [CrossRef] [PubMed]

28. Meehan, M.; Penckofer, S. The Role of Vitamin D in the Aging Adult. J. Aging Gerontol. 2014, 2, 60-71. [CrossRef]

29. Libertini, G.; Corbi, G.; Cellurale, M.; Ferrara, N. Age-Related Dysfunctions: Evidence and Relationship with Some Risk Factors and Protective Drugs. Biochemistry 2019, 84, 1442-1450. [CrossRef]

30. Guan, W.J.; Ni, Z.Y.; Hu, Y.; Liang, W.H.; Ou, C.Q.; He, J.X.; Liu, L.; Shan, H.; Lei, C.L.; Hui, D.S.C.; et al. China Medical Treatment Expert Group for Covid-19. Clinical Characteristics of Coronavirus Disease 2019 in China. N. Engl. J. Med. 2020, 382, 1708-1720. [CrossRef] 
31. Zhao, S.; Cao, P.; Chong, M.K.C.; Gao, D.; Lou, Y.; Ran, J.; Wang, K.; Wang, W.; Yang, L.; He, D.; et al. COVID-19 and genderspecific difference: Analysis of public surveillance data in Hong Kong and Shenzhen, China, from January 10 to February 15, 2020. Infect Control Hosp. Epidemiol. 2020, 41, 750-751. [CrossRef]

32. Mo, P.; Xing, Y.; Xiao, Y.; Deng, L.; Zhao, Q.; Wang, H.; Xiong, Y.; Cheng, Z.; Gao, S.; Liang, K.; et al. Clinical characteristics of refractory COVID-19 pneumonia in Wuhan, China. Clin. Infect Dis. 2020, 16, ciaa270. [CrossRef]

33. Jin, J.M.; Bai, P.; He, W.; Wu, F.; Liu, X.F.; Han, D.M.; Liu, S.; Yang, J.K. Gender Differences in Patients with COVID-19: Focus on Severity and Mortality. Front. Public Health 2020, 8, 152. [CrossRef]

34. Bienvenu, L.A.; Noonan, J.; Wang, X.; Peter, K. Higher mortality of COVID-19 in males: Sex differences in immune response and cardiovascular comorbidities. Cardiovasc. Res. 2020, 116, 2197-2206. [CrossRef] [PubMed]

35. Global Health 5050. COVID-19 Sex-Disaggregated Data Tracker. 2020. Available online: https://globalhealth5050.org/covid19/ sexdisaggregated-data-tracker (accessed on 20 October 2020).

36. Gebhard, C.; Regitz-Zagrosek, V.; Neuhauser, H.K.; Morgan, R.; Klein, S.L. Impact of sex and gender on COVID-19 outcomes in Europe. Biol. Sex Differ. 2020, 11, 29. [CrossRef] [PubMed]

37. Ortolan, A.; Lorenzin, M.; Felicetti, M.; Doria, A.; Ramonda, R. Does gender influence clinical expression and disease outcomes in COVID-19? A systematic review and meta-analysis. Int. J. Infect Dis. 2020, 99, 496-504. [CrossRef]

38. Sharma, G.; Volgman, A.S.; Michos, E.D. Sex Differences in Mortality From COVID-19 Pandemic: Are Men Vulnerable and Women Protected? JACC Case Rep. 2020, 2, 1407-1410. [CrossRef] [PubMed]

39. Smith, J.A.; Griffith, D.M.; White, A.; Baker, P.; Watkins, D.C.; Drummond, M.; Semlowm, A. COVID-19, equity and men's health: Using evidence to inform future public health policy, practice and research responses to pandemics. Int. J. Men. Soc. Commun. Health 2020, 3, e48-e64. [CrossRef]

40. Bischof, E.; Wolfe, J.; Klein, S.L. Clinical trials for COVID-19 should include sex as a variable. J. Clin. Investig. 2020, 130, 3350-3352. [CrossRef]

41. Williamson, E.J.; Walker, A.J.; Bhaskaran, K.; Bacon, S.; Bates, C.; Morton, C.E.; Curtis, H.J.; Mehrkar, A.; Evans, D.; Inglesby, P.; et al. Factors associated with COVID-19-related death using OpenSAFELY. Nature 2020, 584, 430-436. [CrossRef]

42. Haitao, T.; Vermunt, J.V.; Abeykoon, J.; Ghamrawi, R.; Gunaratne, M.; Jayachandran, M.; Narang, K.; Parashuram, S.; Suvakov, S.; Garovic, V.D. COVID-19 and Sex Differences: Mechanisms and Biomarkers. Mayo Clin. Proc. 2020, 95, 2189-2203. [CrossRef]

43. Mauvais-Jarvis, F.; Klein, S.L.; Levin, E.R. Estradiol, Progesterone, Immunomodulation, and COVID-19 Outcomes. Endocrinology 2020, 161, bqaa127. [CrossRef]

44. Sama, I.E.; Ravera, A.; Santema, B.T.; van Goor, H.; Ter Maaten, J.M.; Cleland, J.G.F.; Rienstra, M.; Friedrich, A.W.; Samani, N.J.; $\mathrm{Ng}$, L.L.; et al. Circulating plasma concentrations of angiotensin-converting enzyme 2 in men and women with heart failure and effects of renin-angiotensin-aldosterone inhibitors. Eur. Heart J. 2020, 41, 1810-1817. [CrossRef]

45. Nelson, C.P.; Sama, I.E.; Codd, V.; Webb Thomas, R.; Ye, S.; Lang, C.C.; Voors, A.A.; Ng, L.L.; Samani, N.J. Genetic associations with plasma ACE2 concentration: Potential relevance to COVID-19 risk. Circulation 2020, 142, 1117-1119. [CrossRef] [PubMed]

46. Pradhan, A.; Olsson, P.E. Sex differences in severity and mortality from COVID-19: Are males more vulnerable? Biol. Sex Differ. 2020, 18, 53. [CrossRef] [PubMed]

47. Baker, P.; White, A.; Morgan, R. Men's health: COVID-19 pandemic highlights need for overdue policy action. Lancet 2020, 395, 1886-1888. [CrossRef]

48. Wenham, C.; Smith, J.; Morgan, R. Gender and COVID-19 Working Group. COVID-19: The gendered impacts of the outbreak. Lancet 2020, 395, 846-848. [CrossRef]

49. Griffith, D.M.; Sharma, G.; Holliday, C.S.; Enyia, O.K.; Valliere, M.; Semlow, A.R.; Stewart, E.C.; Blumenthal, R.S. Men and COVID-19: A Biopsychosocial Approach to Understanding Sex Differences in Mortality and Recommendations for Practice and Policy Interventions. Prev. Chronic Dis. 2020, 17, E63. [CrossRef]

50. Galasso, V.; Pons, V.; Profeta, P.; Becher, M.; Brouard, S.; Foucault, M. Gender differences in COVID-19 attitudes and behavior: Panel evidence from eight countries. Proc. Natl. Acad. Sci. USA 2020, 117, 27285-27291. [CrossRef]

51. Pérez-López, F.R.; Tajada, M.; Savirón-Cornudella, R.; Sánchez-Prieto, M.; Chedraui, P.; Terán, E. Coronavirus disease 2019 and gender-related mortality in European countries: A meta-analysis. Maturitas 2020, 141, 59-62. [CrossRef]

52. Robertson, C.; Gebeloff, R. How Millions of Women Became the Most Essential Workers in America. New York Times. 18 April 2020. Available online: https:/ /www.nytimes.com/2020/04/18/us/coronavirus (accessed on 28 December 2020).

53. Costa, F.F.; Rosário, W.R.; Ribeiro Farias, A.C.; de Souza, R.G.; Duarte Gondim, R.S.; Barroso, W.A. Metabolic syndrome and COVID-19: An update on the associated comorbidities and proposed therapies. Diabetes Metab. Syndr. 2020, 14, 809-814. [CrossRef]

54. Hu, Y.; Sun, J.; Dai, Z.; Deng, H.; Li, X.; Huang, Q.; Wu, Y.; Sun, L.; Xu, Y. Prevalence and severity of corona virus disease 2019 (COVID-19): A systematic review and meta-analysis. J. Clin. Virol. 2020, 127, 104371. [CrossRef]

55. Schiffrin, E.L.; Flack, J.M.; Ito, S.; Muntner, P.; Webb, R.C. Hypertension and COVID-19. Am. J. Hypertens. 2020, 33, 373-374. [CrossRef]

56. Grasselli, G.; Zangrillo, A.; Zanella, A.; Antonelli, M.; Cabrini, L.; Castelli, A.; Cereda, D.; Coluccello, A.; Foti, G.; Fumagalli, R.; et al. COVID-19 Lombardy ICU Network. Baseline Characteristics and Outcomes of 1591 Patients Infected With SARS-CoV-2 Admitted to ICUs of the Lombardy Region, Italy. JAMA 2020, 323, 1574-1581. [CrossRef] [PubMed] 
57. Richardson, S.; Hirsch, J.S.; Narasimhan, M.; Crawford, J.M.; McGinn, T.; Davidson, K.W.; The Northwell COVID-19 Research Consortium; Barnaby, D.P.; Becker, L.B.; Chelico, J.D.; et al. Presenting Characteristics, Comorbidities, and Outcomes Among 5700 Patients Hospitalized With COVID-19 in the New York City Area. JAMA 2020, 323, 2052-2059. [CrossRef] [PubMed]

58. Shibata, S.; Arima, H.; Asayama, K.; Hoshide, S.; Ichihara, A.; Ishimitsu, T.; Kario, K.; Kishi, T.; Mogi, M.; Nishiyama, A.; et al. Hypertension and related diseases in the era of COVID-19: A report from the Japanese Society of Hypertension Task Force on COVID-19. Hypertens. Res. 2020, 43, 1028-1046. [CrossRef] [PubMed]

59. Zaki, N.; Alashwal, H.; Ibrahim, S. Association of hypertension, diabetes, stroke, cancer, kidney disease, and high-cholesterol with COVID-19 disease severity and fatality: A systematic review. Diabetes Metab. Syndr. 2020, 14, 1133-1142. [CrossRef]

60. Zekavat, S.M.; Honigberg, M.; Pirruccello, J.; Kohli, P.; Karlson, E.W.; Newton-Cheh, C.; Zhao, H.; Natarajan, P. Influence of blood pressure on pneumonia risk: Epidemiological association and Mendelian randomisation in the UK Biobank. medRxiv 2020. [CrossRef]

61. Shi, S.; Qin, M.; Shen, B.; Cai, Y.; Liu, T.; Yang, F.; Gong, W.; Liu, X.; Liang, J.; Zhao, Q.; et al. Association of Cardiac Injury With Mortality in Hospitalized Patients With COVID-19 in Wuhan, China. JAMA Cardiol. 2020, 5, 802-810. [CrossRef]

62. Li, B.; Yang, J.; Zhao, F.; Zhi, L.; Wang, X.; Liu, L.; Bi, Z.; Zhao, Y. Prevalence and impact of cardiovascular metabolic diseases on COVID-19 in China. Clin. Res. Cardiol. 2020, 109, 531-538. [CrossRef]

63. Tadic, M.; Cuspidi, C.; Grassi, G.; Mancia, G. COVID-19 and arterial hypertension: Hypothesis or evidence? J. Clin. Hypertens. 2020, 22, 1120-1126. [CrossRef]

64. Matsushita, K.; Ding, N.; Kou, M.; Hu, X.; Chen, M.; Gao, Y.; Honda, Y.; Zhao, D.; Dowdy, D.; Mok, Y.; et al. The Relationship of COVID-19 Severity with Cardiovascular Disease and Its Traditional Risk Factors: A Systematic Review and Meta-Analysis. Glob. Heart 2020, 15, 64. [CrossRef]

65. Azevedo, R.B.; Botelho, B.G.; Hollanda, J.V.G.; Ferreira, L.V.L.; Junqueira de Andrade, L.Z.; Oei, S.S.M.L.; Mello, T.S.; Muxfeldt, E.S. Covid-19 and the cardiovascular system: A comprehensive review. J. Hum. Hypertens. 2020, 27, 1-8. [CrossRef]

66. Kreutz, R.; Algharably, E.A.E.; Azizi, M.; Dobrowolski, P.; Guzik, T.; Januszewicz, A.; Persu, A.; Prejbisz, A.; Riemer, T.G.; Wang, J.G.; et al. Hypertension, the renin-angiotensin system, and the risk of lower respiratory tract infections and lung injury: Implications for COVID-19. Cardiovasc. Res. 2020, 116, 1688-1699. [CrossRef]

67. Chen, Y.; Gong, X.; Wang, L.; Guo, J. Effects of hypertension, diabetes and coronary heart disease on COVID-19 diseases severity: A systematic review and metaanalysis. medRxiv 2020. [CrossRef]

68. Zuin, M.; Rigatelli, G.; Zuliani, G.; Rigatelli, A.; Mazza, A.; Roncon, L. Arterial hypertension and risk of death in patients with COVID-19 infection: Systematic review and meta-analysis. J. Infect. 2020, 81, e84-e86. [CrossRef]

69. Wang, Z.; Chen, Z.; Zhang, L.; Wang, X.; Hao, G.; Zhang, Z.; Shao, L.; Tian, Y.; Dong, Y.; Zheng, C.; et al. Status of Hypertension in China: Results From the China Hypertension Survey, 2012-2015. Circulation 2018, 137, 2344-2356. [CrossRef]

70. Tocci, G.; Nati, G.; Cricelli, C.; Parretti, D.; Lapi, F.; Ferrucci, A.; Borghi, C.; Volpe, M. Prevalence and control of hypertension in the general practice in Italy: Updated analysis of a large database. J. Hum. Hypertens. 2017, 31, 258-262. [CrossRef]

71. Whelton, P.K.; Carey, R.M.; Aronow, W.S.; Casey, D.E., Jr.; Collins, K.J.; Dennison Himmelfarb, C.; DePalma, S.M.; Gidding, S.; Jamerson, K.A.; Jones, D.W.; et al. 2017 ACC/AHA/AAPA/ABC/ACPM/AGS/APhA/ASH/ASPC/NMA/PCNA Guideline for the Prevention, Detection, Evaluation, and Management of High Blood Pressure in Adults: Executive Summary: A Report of the American College of Cardiology/American Heart Association Task Force on Clinical Practice Guidelines. Hypertension 2018, $71,1269-1324$.

72. De Almeida-Pititto, B.; Dualib, P.M.; Zajdenverg, L.; Dantas, J.R.; de Souza, F.D.; Rodacki, M.; Bertoluci, M.C.; Brazilian Diabetes Society Study Group (SBD). Severity and mortality of COVID 19 in patients with diabetes, hypertension and cardiovascular disease: A meta-analysis. Diabetol. Metab. Syndr. 2020, 12, 75. [CrossRef]

73. Bansal, M. Cardiovascular disease and COVID-19. Diabetes Metab. Syndr. 2020, 14, 247-250. [CrossRef]

74. Moula, A.I.; Micali, L.R.; Matteucci, F.; Lucà, F.; Rao, C.M.; Parise, O.; Parise, G.; Gulizia, M.M.; Gelsomino, S. Quantification of Death Risk in Relation to Sex, Pre-Existing Cardiovascular Diseases and Risk Factors in COVID-19 Patients: Let's Take Stock and See Where We Are. J. Clin. Med. 2020, 9, 2685. [CrossRef]

75. Pranata, R.; Huang, I.; Lim, M.A.; Wahjoepramono, E.J.; July, J. Impact of cerebrovascular and cardiovascular diseases on mortality and severity of COVID-19-systematic review, meta-analysis, and meta-regression. J. Stroke Cereb. Dis. 2020, 29, 104949. [CrossRef]

76. Zheng, Z.; Peng, F.; Xu, B.; Zhao, J.; Liu, H.; Peng, J.; Li, Q.; Jiang, C.; Zhou, Y.; Liu, S.; et al. Risk factors of critical \& mortal COVID-19 cases: A systematic literature review and meta-analysis. J. Infect. 2020, 81, e16-e25.

77. Dherange, P.; Lang, J.; Qian, P.; Oberfeld, B.; Sauer, W.H.; Koplan, B.; Tedrow, U. Arrhythmias and COVID-19: A Review. JACC Clin. Electrophysiol. 2020, 6, 1193-1204. [CrossRef]

78. Bhatla, A.; Mayer, M.M.; Adusumalli, S.; Hyman, M.C.; Oh, E.; Tierney, A.; Moss, J.; Chahal, A.A.; Anesi, G.; Denduluri, S.; et al. COVID-19 and cardiac arrhythmias. Heart Rhythm. 2020, 17, 1439-1444. [CrossRef]

79. Apicella, M.; Campopiano, M.C.; Mantuano, M.; Mazoni, L.; Coppelli, A.; Del Prato, S. COVID-19 in people with diabetes: Understanding the reasons for worse outcomes. Lancet Diabetes Endocrinol. 2020, 8, 782-792. [CrossRef]

80. Du, M.; Lin, Y.X.; Yan, W.X.; Tao, L.Y.; Liu, M.; Liu, J. Prevalence and impact of diabetes in patients with COVID-19 in China. World J. Diabetes 2020, 11, 468-480. [CrossRef] 
81. Centers for Disease Control- CDC COVID-19 Response Team. Preliminary Estimates of the Prevalence of Selected Underlying Health Conditions Among Patients with Coronavirus Disease 2019-United States, February 12-March 28, 2020. MMWR Morb. Mortal. Wkly Rep. 2020, 69, 382-386. [CrossRef]

82. Lisco, G.; De Tullio, A.; Giagulli, V.A.; Guastamacchia, E.; De Pergola, G.; Triggiani, V. Hypothesized mechanisms explaining poor prognosis in type 2 diabetes patients with COVID-19: A review. Endocrine 2020, 70, 441-453. [CrossRef]

83. Petrilli, C.M.; Jones, S.A.; Yang, J.; Rajagopalan, H.; O’Donnell, L.; Chernyak, Y.; Tobin, K.A.; Cerfolio, R.J.; Francois, F.; Horwitz, L.I. Factors Associated with Hospitalization and Critical Illness Among 4,103 Patients with COVID-19 Disease in New York City. Available online: https://www.medrxiv.org/content/10.1101/2020.04.08.20057794v1 (accessed on 28 December 2020).

84. Singh, A.K.; Gupta, R.; Ghosh, A.; Misra, A. Diabetes in COVID-19: Prevalence, pathophysiology, prognosis and practical considerations. Diabetes Metab. Syndr. 2020, 14, 303-310. [CrossRef]

85. Zhou, F.; Yu, T.; Du, R.; Fan, G.; Liu, Y.; Liu, Z.; Xiang, J.; Wang, Y.; Song, B.; Gu, X.; et al. Clinical course and risk factors for mortality of adult inpatients with COVID-19 in Wuhan, China: A retrospective cohort study. Lancet 2020, 395, $1054-1062$. [CrossRef]

86. Barron, E.; Bakhai, C.; Kar, P.; Weaver, A.; Bradley, D.; Ismail, H.; Knighton, P.; Holman, N.; Khunti, K.; Sattar, N.; et al. Associations of type 1 and type 2 diabetes with COVID-19-related mortality in England: A whole-population study. Lancet Diabetes Endocrinol. 2020, 8, 813-822. [CrossRef]

87. Guo, W.; Li, M.; Dong, Y.; Zhou, H.; Zhang, Z.; Tian, C.; Qin, R.; Wang, H.; Shen, Y.; Du, K.; et al. Diabetes is a risk factor for the progression and prognosis of COVID-19. Diabetes Metab. Res. Rev. 2020, 31, e3319. [CrossRef]

88. Zhang, Y.; Cui, Y.; Shen, M.; Zhang, J.; Liu, B. Comorbid diabetes mellitus was associated with poorer prognosis in patients with COVID-19: A retrospective cohort study. medRxiv. 2020. Available online: https://www.medrxiv.org/content/10.1101/2020.03. 24.20042358v1 (accessed on 28 December 2020).

89. Wu, Z.; McGoogan, J.M. Characteristics of and Important Lessons From the Coronavirus Disease 2019 (COVID-19) Outbreak in China: Summary of a Report of 72314 Cases From the Chinese Center for Disease Control and Prevention. JAMA 2020, 323, 1239-1242. [CrossRef]

90. Cariou, B.; Hadjadj, S.; Wargny, M.; Pichelin, M.; Al-Salameh, A.; Allix, I.; Amadou, C.; Arnault, G.; Baudoux, F.; Bauduceau, B.; et al. Phenotypic characteristics and prognosis of inpatients with COVID-19 and diabetes: The CORONADO study. Diabetologia 2020, 63, 1500-1515. [CrossRef]

91. Holman, N.; Knighton, P.; Kar, P.; O’Keefe, J.; Curley, M.; Weaver, A.; Barron, E.; Bakhai, C.; Khunti, K.; Wareham, N.J.; et al. Risk factors for COVID-19-related mortality in people with type 1 and type 2 diabetes in England: A population-based cohort study. Lancet Diabetes Endocrinol. 2020, 8, 823-833. [CrossRef]

92. Pugliese, G.; Vitale, M.; Resi, V.; Orsi, E. Is diabetes mellitus a risk factor for COronaVIrus Disease 19 (COVID-19)? Acta Diabetol. 2020, 57, 1275-1285. [CrossRef]

93. Rychter, A.M.; Zawada, A.; Ratajczak, A.E.; Dobrowolska, A.; Krela-Kaźmierczak, I. Should patients with obesity be more afraid of COVID-19? Obes. Rev. 2020, 21, e13083. [CrossRef]

94. Puig-Domingo, M.; Marazuela, M.; Giustina, A. COVID-19 and endocrine diseases. A statement from the European Society of Endocrinology. Endocrine 2020, 68, 2-5. [CrossRef]

95. Finer, N.; Garnett, S.P.; Bruun, J.M. COVID-19 and obesity. Clin. Obes. 2020, 10, e12365. [CrossRef]

96. Caci, G.; Albini, A.; Malerba, M.; Noonan, D.M.; Pochetti, P.; Polosa, R. COVID-19 and Obesity: Dangerous Liaisons. J. Clin. Med. 2020, 9, 2511. [CrossRef]

97. Lighter, J.; Phillips, M.; Hochman, S.; Sterling, S.; Johnson, D.; Francois, F.; Stachel, A. Obesity in Patients Younger Than 60 Years Is a Risk Factor for COVID-19 Hospital Admission. Clin. Infect. Dis. 2020, 71, 896-897. [CrossRef]

98. Hu, X.; Pan, X.; Zhou, W.; Gu, X.; Shen, F.; Yang, B.; Hu, Z. Clinical epidemiological analyses of overweight/obesity and abnormal liver function contributing to prolonged hospitalization in patients infected with COVID-19. Int. J. Obes. 2020, 44, $1784-1789$. [CrossRef]

99. Yates, T.; Razieh, C.; Zaccardi, F.; Davies, M.J.; Khunti, K. Obesity and risk of COVID-19: Analysis of UK biobank. Prim. Care Diabetes 2020, 14, 566-567. [CrossRef]

100. Simonnet, A.; Chetboun, M.; Poissy, J.; Raverdy, V.; Noulette, J.; Duhamel, A.; Labreuche, J.; Mathieu, D.; Pattou, F.; Jourdain, M.; et al. High Prevalence of Obesity in Severe Acute Respiratory Syndrome Coronavirus-2 (SARS-CoV-2) Requiring Invasive Mechanical Ventilation. Obesity 2020, 28, 1195-1199. [CrossRef]

101. Korakas, E.; Ikonomidis, I.; Kousathana, F.; Balampanis, K.; Kountouri, A.; Raptis, A.; Palaiodimou, L.; Kokkinos, A.; Lambadiari, V. Obesity and COVID-19: Immune and metabolic derangement as a possible link to adverse clinical outcomes. Am. J. Physiol. Endocrinol. Metab. 2020, 319, E105-E109. [CrossRef]

102. Dreher, M.; Kersten, A.; Bickenbach, J.; Balfanz, P.; Hartmann, B.; Cornelissen, C.; Daher, A.; Stöhr, R.; Kleines, M.; Lemmen, S.W.; et al. The Characteristics of 50 Hospitalized COVID-19 Patients with and Without ARDS. Dtsch. Arztebl. Int. 2020, 117, $271-278$.

103. Piva, S.; Filippini, M.; Turla, F.; Cattaneo, S.; Margola, A.; De Fulviis, S.; Nardiello, I.; Beretta, A.; Ferrari, L.; Trotta, R.; et al. Clinical presentation and initial management critically ill patients with severe acute respiratory syndrome coronavirus 2 (SARS-CoV-2) infection in Brescia, Italy. J. Crit. Care 2020, 58, 29-33. [CrossRef]

104. Busetto, L.; Bettini, S.; Fabris, R.; Serra, R.; Dal Pra, C.; Maffei, P.; Rossato, M.; Fioretto, P.; Vettor, R. Obesity and COVID-19: An Italian Snapshot. Obesity 2020, 28, 1600-1605. [CrossRef] 
105. Kalligeros, M.; Shehadeh, F.; Mylona, E.K.; Benitez, G.; Beckwith, C.G.; Chan, P.A.; Mylonakis, E. Association of Obesity with Disease Severity Among Patients with Coronavirus Disease 2019. Obesity 2020, 28, 1200-1204. [CrossRef]

106. Simpson, A.H.R.; Simpson, C.J.; Frost, H.; Welburn, S.C. COVID-19: Obesity, deprivation and death. J. Glob. Health 2020, 10, 020389. [CrossRef]

107. Zhang, F.; Xiong, Y.; Wei, Y.; Hu, Y.; Wang, F.; Li, G.; Liu, K.; Du, R.; Wang, C.Y.; Zhu, W. Obesity predisposes to the risk of higher mortality in young COVID-19 patients. J. Med. Virol. 2020, 92, 2536-2542. [CrossRef]

108. Huang, Y.; Lu, Y.; Huang, Y.M.; Wang, M.; Ling, W.; Sui, Y.; Zhao, H.L. Obesity in patients with COVID-19: A systematic review and meta-analysis. Metabolism 2020, 113, 154378. [CrossRef]

109. Azzolino, D.; Cesari, M. Obesity and COVID-19. Front. Endocrinol. 2020, 11, 581356. [CrossRef]

110. Muscogiuri, G.; Pugliese, G.; Barrea, L.; Savastano, S.; Colao, A. Commentary: Obesity: The "Achilles heel" for COVID-19? Metabolism 2020, 108, 154251. [CrossRef]

111. Sattar, N.; McInnes, I.B.; McMurray, J.J.V. Obesity Is a Risk Factor for Severe COVID-19 Infection: Multiple Potential Mechanisms. Circulation 2020, 142, 4-6. [CrossRef]

112. Dietz, W.; Santos-Burgoa, C. Obesity and its Implications for COVID-19 Mortality. Obesity 2020, 28, 1005. [CrossRef]

113. Liu, C.; Zhao, Y.; Okwan-Duodu, D.; Basho, R.; Cui, X. COVID-19 in cancer patients: Risk, clinical features, and management. Cancer Biol. Med. 2020, 17, 519-527.

114. Kuderer, N.M.; Lyman, G.H. COVID-19, Cancer, and Consequences: Where Are We Now? Cancer Investig. 2020, $38,431-435$. [CrossRef]

115. Liang, W.; Guan, W.; Chen, R.; Wang, W.; Li, J.; Xu, K.; Li, C.; Ai, Q.; Lu, W.; Liang, H.; et al. Cancer patients in SARS-CoV-2 infection: A nationwide analysis in China. Lancet Oncol. 2020, 21, 335-337. [CrossRef]

116. Kuderer, N.M.; Choueiri, T.K.; Shah, D.P.; Shyr, Y.; Rubinstein, S.M.; Rivera, D.R.; Shete, S.; Hsu, C.Y.; Desai, A.; de Lima Lopes, G.; et al. Clinical impact of COVID-19 on patients with cancer (CCC19): A cohort study. Lancet 2020, 395, 1907-1918. [CrossRef]

117. Dai, M.; Liu, D.; Liu, M.; Zhou, F.; Li, G.; Chen, Z.; Zhang, Z.; You, H.; Wu, M.; Zheng, Q.; et al. Patients with Cancer Appear More Vulnerable to SARS-CoV-2: A Multicenter Study during the COVID-19 Outbreak. Cancer Discov. 2020, 10, 783-791.

118. Zhang, L.; Zhu, F.; Xie, L.; Wang, C.; Wang, J.; Chen, R.; Jia, P.; Guan, H.Q.; Peng, L.; Chen, Y.; et al. Clinical characteristics of COVID-19-infected cancer patients: A retrospective case study in three hospitals within Wuhan, China. Ann. Oncol. 2020, 31, 894-901. [CrossRef]

119. Addeo, A.; Friedlaender, A. Cancer and COVID-19: Unmasking their ties. Cancer Treat Rev. 2020, 88, 102041. [CrossRef]

120. Yang, K.; Sheng, Y.; Huang, C.; Jin, Y.; Xiong, N.; Jiang, K.; Lu, H.; Liu, J.; Yang, J.; Dong, Y.; et al. Clinical characteristics, outcomes, and risk factors for mortality in patients with cancer and COVID-19 in Hubei, China: A multicentre, retrospective, cohort study. Lancet Oncol. 2020, 21, 904-913. [CrossRef]

121. Sanchez-Ramirez, D.C.; Mackey, D. Underlying respiratory diseases, specifically COPD, and smoking are associated with severe COVID-19 outcomes: A systematic review and meta-analysis. Respir. Med. 2020, 171, 106096. [CrossRef]

122. Zhang, J.J.; Dong, X.; Cao, Y.Y.; Yuan, Y.D.; Yang, Y.B.; Yan, Y.Q.; Akdis, C.A.; Gao, Y.D. Clinical characteristics of 140 patients infected with SARS-CoV-2 in Wuhan, China. Allergy 2020, 75, 1730-1741. [CrossRef]

123. Yang, J.; Zheng, Y.; Gou, X.; Pu, K.; Chen, Z.; Guo, Q.; Ji, R.; Wang, H.; Wang, Y.; Zhou, Y. Prevalence of comorbidities and its effects in patients infected with SARS-CoV-2: A systematic review and meta-analysis. Int. J. Infect. Dis. 2020, 94, 91-95. [CrossRef]

124. Zhao, Q.; Meng, M.; Kumar, R.; Wu, Y.; Huang, J.; Lian, N.; Deng, Y.; Lin, S. The impact of COPD and smoking history on the severity of COVID-19: A systemic review and meta-analysis. J. Med. Virol. 2020, 92, 1915-1921. [CrossRef]

125. Liu, S.; Zhi, Y.; Ying, S. COVID-19 and Asthma: Reflection During the Pandemic. Clin. Rev. Allergy Immunol. 2020, 59, 78-88. [CrossRef]

126. Morais-Almeida, M.; Pité, H.; Aguiar, R.; Ansotegui, I.; Bousquet, J. Asthma and the Coronavirus Disease 2019 Pandemic: A Literature Review. Int. Arch. Allergy Immunol. 2020, 181, 680-688. [CrossRef]

127. Kastritis, E.; Kitas, G.D.; Vassilopoulos, D.; Giannopoulos, G.; Dimopoulos, M.A.; Sfikakis, P.P. Systemic autoimmune diseases, anti-rheumatic therapies, COVID-19 infection risk and patient outcomes. Rheumatol. Int. 2020, 40, 1353-1360. [CrossRef]

128. Akiyama, S.; Hamdeh, S.; Micic, D.; Sakuraba, A. Prevalence and clinical outcomes of COVID-19 in patients with autoimmune diseases: A systematic review and meta-analysis. Ann. Rheum. Dis. 2020, in press. [CrossRef]

129. Ferri, C.; Giuggioli, D.; Raimondo, V.; L'Andolina, M.; Tavoni, A.; Cecchetti, R.; Guiducci, S.; Ursini, F.; Caminiti, M.; Varcasia, G.; et al. COVID-19 and rheumatic autoimmune systemic diseases: Report of a large Italian patients series. Clin. Rheumatol. 2020, 39, 3195-3204. [CrossRef] [PubMed]

130. Liu, Y.; Sawalha, A.H.; Lu, Q. COVID-19 and autoimmune diseases. Curr. Opin. Rheumatol. 2020. [CrossRef] [PubMed]

131. Ehrenfeld, M.; Tincani, A.; Andreoli, L.; Cattalini, M.; Greenbaum, A.; Kanduc, D.; Alijotas-Reig, J.; Zinserling, V.; Semenova, N.; Amital, H.; et al. Covid-19 and autoimmunity. Autoimmun. Rev. 2020, 19, 102597. [CrossRef]

132. Haberman, R.; Axelrad, J.; Chen, A.; Castillo, R.; Yan, D.; Izmirly, P.; Neimann, A.; Adhikari, S.; Hudesman, D.; Scher, J.U. Covid-19 in Immune-Mediated Inflammatory Diseases-Case Series from New York. N. Engl. J. Med. 2020, 383, 85-88. [CrossRef]

133. Monti, S.; Balduzzi, S.; Delvino, P.; Bellis, E.; Quadrelli, V.S.; Montecucco, C. Clinical course of COVID-19 in a series of patients with chronic arthritis treated with immunosuppressive targeted therapies. Ann. Rheum. Dis. 2020, 79, 667-668. [CrossRef]

134. Cook, T.M.; El-Boghdadly, K. COVID-19 risk tools should incorporate assessment of working environment risk and its mitigation. EClinicalMedicine 2020, 28, 100613. [CrossRef] 
135. Marinaccio, A.; Guerra, R.; Iavicoli, S. Work a key determinant in COVID-19 risk. Lancet Glob. Health 2020, 8, e1368. [CrossRef]

136. ECDC, European Centre for Disease Prevention and Control. COVID-19 Clusters and Outbreaks in Occupational Settings in the EU/EEA and the UK. 11 August 2020. Available online: https://www.ecdc.europa.eu/en/publications-data/covid-19-clustersand-outbreaks-occupational-settings-eueea-and-uk (accessed on 19 January 2021).

137. Sim, M.R. The COVID-19 pandemic: Major risks to healthcare and other workers on the front line. Occup. Environ. Med. 2020, 77, 281-282. [CrossRef]

138. Marinaccio, A.; Boccuni, F.; Rondinone, B.M.; Brusco, A.; D'Amario, S.; Iavicoli, S. Occupational factors in the COVID-19 pandemic in Italy: Compensation claims applications support establishing an occupational surveillance system. Occup. Environ. Med. 2020, 77, 818-821. [CrossRef]

139. OSHA, Occupational Safety and Health Administration. Guidance for Preparing Workplaces for COVID-19. Available online: https: / / www.osha.gov / Publications /OSHA3990.pdf (accessed on 19 January 2021).

140. Zisook, R.E.; Monnot, A.; Parker, J.; Gaffney, S.; Dotson, S.; Unice, K. Assessing and managing the risks of COVID-19 in the workplace: Applying industrial hygiene (IH)/occupational and environmental health and safety (OEHS) frameworks. Toxicol. Ind. Health 2020, 36, 607-618. [CrossRef] [PubMed]

141. Hill, K.S. Nursing and the aging workforce: Myths and reality, what do we really know? Nurs. Clin. N. Am. 2011, 46, 1-9. [CrossRef]

142. Eurofound. Ageing workforce. 12 November 2020. Available online: https://www.eurofound.europa.eu/topic/ageingworkforce (accessed on 19 January 2021).

143. Behling, D.; Guy, J. Who's protected? Legal, ethical issues in employing the immunosuppressed. Occup. Health Saf. 1993, 62, 76-79. [PubMed]

144. Spiegelhalter, D. How old are you, really? Communicating chronic risk through 'effective age' of your body and organs. BMC Med. Inform. Decis. Mak. 2016, 16, 104. [CrossRef] [PubMed]

145. Vicente-Herrero, T.; de la Torre, V.R.I.; del Campo Balsa, T.; Barbero, L.R.; Montenero, A.F.; Garrido, J.C.R. Proposed Protocol for Risk Assessment and Stratification. Occup. Dis. Environ. Med. 2020, 5, 99-110. [CrossRef]

146. Preskorn, S.H. The 5\% of the Population at High Risk for Severe COVID-19 Infection Is Identifiable and Needs to Be Taken Into Account When Reopening the Economy. J. Psychiatr. Pract. 2020, 26, 219-227. [CrossRef]

147. NHS, National Health Service. National Guidance for post-COVID Syndrome Assessment Clinics. Available online: https: / / www.england.nhs.uk/coronavirus/wp-content/uploads/sites/52/2020/11/C0840-national-guidance-for-postcovid-syndrome-assesment-clinics-111220.pdf (accessed on 28 December 2020).

148. Kamal, M.; Abo Omirah, M.; Hussein, A.; Saeed, H. Assessment and characterisation of post-COVID-19 manifestations. Int. J. Clin. Pract. 2020, 29, e13746.

149. Halpin, S.J.; McIvor, C.; Whyatt, G.; Adams, A.; Harvey, O.; McLean, L.; Walshaw, C.; Kemp, S.; Corrado, J.; Singh, R.; et al. Postdischarge symptoms and rehabilitation needs in survivors of COVID-19 infection: A cross-sectional evaluation. J. Med. Virol. 2020, in press. [CrossRef]

150. Abbatecola, A.M.; Antonelli-Incalzi, R. Editorial: COVID-19 Spiraling of Frailty in Older Italian Patients. J. Nutr. Health Aging 2020, 24, 453-455. [CrossRef]

151. Maltese, G.; Corsonello, A.; Di Rosa, M.; Soraci, L.; Vitale, C.; Corica, F.; Lattanzio, F. Frailty and COVID-19: A Systematic Scoping Review. J. Clin. Med. 2020, 9, 2106. [CrossRef]

152. Vincent, J.L.; Taccone, F.S. Understanding pathways to death in patients with COVID-19. Lancet Respir. Med. 2020, 8, 430-432. [CrossRef]

153. Volpato, S.; Landi, F.; Incalzi, R.A. A Frail Health Care System for an Old Population: Lesson form the COVID-19 Outbreak in Italy. J. Gerontol. A Biol. Sci. Med. Sci. 2020, 75, e126-e127. [CrossRef] [PubMed]

154. Moccia, F.; Gerbino, A.; Lionetti, V.; Miragoli, M.; Munaron, L.M.; Pagliaro, P.; Pasqua, T.; Penna, C.; Rocca, C.; Samaja, M.; et al. COVID-19-associated cardiovascular morbidity in older adults: A position paper from the Italian Society of Cardiovascular Researches. Geroscience 2020, 42, 1021-1049. [CrossRef] [PubMed]

155. Silver, J.K. Prehabilitation May Help Mitigate an Increase in COVID-19 Peripandemic Surgical Morbidity and Mortality. Am. J. Phys. Med. Rehabil. 2020, 99, 459-463. [PubMed]

156. Heckman, G.A.; Saari, M.; McArthur, C.; Wellens, N.I.H.; Hirdes, J.P. COVID-19 outbreak measures may indirectly lead to greater burden on hospitals. CMAJ 2020, 192, E384. [CrossRef] [PubMed]

157. Mina, M.J.; Metcalf, C.J.E.; McDermott, A.B.; Douek, D.C.; Farrar, J.; Grenfell, B.T. A Global lmmunological Observatory to meet a time of pandemics. eLife 2020, 8, e58989. [CrossRef]

158. Sinclair, A.J.; Abdelhafiz, A.H. Age, frailty and diabetes-triple jeopardy for vulnerability to COVID-19 infection. EClinicalMedicine 2020, 22, 100343. [CrossRef]

159. SOM-Supporting Occupational Health and Wellbeing Professionals). COVID-19 Return to Work Guide for Health Professionals Advising Patients and Employers. September 2020. Available online: https://www.som.org.uk/sites/som.org.uk/files/COVID19_Return_to_Work_Guide_for_Occupational_Health_Professionals.html (accessed on 28 December 2020). 